


\title{
Evaluation of Reuse of Wastewater in Agriculture in Turkey: Outbreak Perspective of Covid-19
}

\section{Kovid-19 Pandemisi Çerçevesinde Türkiye'de Kullanılmış Suların Tarımda Yeniden Kullanılmasının Değerlendirmesi}

\author{
Numan Habip*, Yusuf Başaran, Arife Özüdoğru, Osman Özdemir, Onur Altun, \\ Yakup Karaaslan, Bilal Dikmen \\ Republic of Turkey, Ministry of Agriculture and Forestry, General Directorate of Water Management, \\ 06510, Yenimahalle-Ankara-Turkey \\ numan.habip@tarimorman.gov.tr (https://orcid.org/0000-0002-0814-7045), basaran.yusuf@, \\ tarimorman.gov.tr (https://orcid.org/0000-0002-6662-3265), arife.ozudogru@tarimorman.gov. \\ tr (https://orcid.org/0000-0001-8601-6369), osman.ozdemir@tarimorman.gov.tr (https://orcid. \\ org/0000-0003-3311-0815),onur.altun@tarimorman.gov.tr (https://orcid.org/0000-0002-1873- \\ 9546), yakup.karaaslan@tarimorman.gov.tr (https://orcid.org/0000-0001-8993-4771), bilaldikmen@ \\ tarimorman.gov.tr (https://orcid.org/0000-0002-8333-5310) \\ Received Date: 05.06.2020, Accepted Date: 16.05.2020 \\ DOI: $10.31807 /$ tjwsm. 748590
}

\begin{abstract}
The recent outbreak of novel coronavirus disease 2019 has become a public health emergency worldwide. The virus, SARS-CoV-2 is spread by human to human transmission via droplets or direct contact. Although there is no evidence of its transmission from wastewater, the virus has been discovered in wastewater. Recent studies showed that SARS-CoV-2 is very sensitive to oxidants such as chlorine. Therefore, disinfection units of treatment plants need to be operated to avoid virus existence in the environment. Moreover, the disinfection process is vital if treated water is going to be used in irrigation. More than one-third of the effluents of wastewater treatment plants in Turkey reaches to agricultural irrigation facilities. The majority of these waste water treatment plants do not have a disinfection unit. Agricultural areas irrigated with treated wastewater have a rich crop pattern in Turkey. Almost half of these agricultural areas used to grow raw-consumable products. Therefore, disinfection units need to be operated properly and the facilities without disinfection unit should be revised. Moreover, regulations are not comprehensive to prevent public health in terms of reuse of wastewater in agriculture in Turkey. There are one regulation and one standard available considering reuse of wastewater in irrigation but neither of them is not covering indirect reuse of treated wastewater in the downstream. Therefore, to prevent public health it is needed to update regulations to include indirect reuse of wastewater.
\end{abstract}

Keywords: Sars-Cov-2, Covid-19, reuse of wastewater, irrigation, waste water treatment plants

Öz

Yakın zamanda ortaya çıkan Kovid-19 hastalığı sebebi ile dünya çapında acil durum ilan edilmiştir. Yapılan araştırmalar bu hastalığa yol açan SARS-CoV-2 virüsünün damlacıklar vasıtasıyla veya temas

\footnotetext{
* Corresponding author
} 
yolu ile bulaştığını göstermiştir. Atıksular yoluyla bulaşmasına ilişkin herhangi bir kanıt olmamasına karşın yapılan çalışmalarda atıksulardaki varlığı gösterilmiştir. Ayrıca, zarflı bir virüs olduğundan klor benzeri oksidanlara karşı dayanıksız olduğu ortaya konulmuştur. Dolayısıyla, virüsün çevredeki varlığının elimine edilmesi için atıksu arıtma tesislerinin dezenfeksiyon ünitelerinin çalıştırılması önem kazanmıştır. Özellikle arıtılmış atık suları doğrudan veya dolaylı olarak sulamada kullanılan tesislerin deşarj işlemi öncesi dezenfeksiyon uygulaması yapılması hayati önem taşımaktadır. Türkiye'deki atıksu arıtma tesislerinin üçte birinden fazlasının suyu sulama tesislerine ulaşmaktadır ve bu tesislerin çoğunluğunda dezenfeksiyon ünitesi bulunmamaktadır. Türkiye'deki arıtılmış atıksular ile sulanan arazilerin ürün deseni çok çeşitlidir ve yarısından fazlasında çiğ tüketilen ürünler üretilmektedir. Bu sebeple, dezenfeksiyon ünitesi bulunan tesisler uygun şekilde dezenfeksiyon işlemi uygulamalıdır ve dezenfeksiyon ünitesi bulunmayan tesisler revize edilmelidir. Ek olarak, kullanılmış suların sulama amaçlı tekrar kullanılması konusunda halk sağlığını korumaya yönelik kapsamlı bir mevzuat bulunmamaktadır. Kullanılmış suların sulama amaçlı yeniden kullanılması konusunda 1 adet mevzuat ve 1 adet standart olmasına rağmen kullanılmış suların mansaplandığı yerlerden dolaylı olarak tekrar kullanılmasını kapsamamaktadır. Dolayısıyla halk sağlığının korunması amacı ile kullanılmış suların dolaylı olarak yeniden kullanılmasını kapsayan mevzuat hazırlanmalıdır.

Anahtar kelimeler: Sars-Cov-2, Kovid-19, kullanılmıss suların yeniden kullanılması, sulama, atıksu arıtma tesisleri

\section{Introduction}

The major portion of the available water, around $70 \%$ in the use of agricultural irrigation, globally (Pimentel \& Pimentel, 2008). Therefore, it has been always an issue to diversify water sources to irrigate. Since ancient times reuse of wastewater in agriculture for crop irrigation has been applied (Angelakis \& Synder, 2015). The main reason for reusing brings many advantages. The main advantages of wastewater reuse are an increase in agricultural productivity, reduction in energy need of productiontreatment, and distribution of water. Moreover, the reusing of wastewater nutrient discharge into the environment decreases (EPA, 2012). Additionally, it is known that to prevent water resources, the reuse of wastewater is an effective method (Manga et al., 2001). Reusing wastewater is not only beneficial to decrease the need for water sources but also gives the opportunity to irrigate during dry seasons or under water shortage situations. On the other hand, dealing with wastewater may become challenging since it includes the following pathogens and chemical substances shown in Table 1. 
Table 1

Chemical and Biological Risks Associated with the Use of Raw Wastewater in Agriculture (WHO, 2006)

\begin{tabular}{|c|c|c|}
\hline \multicolumn{3}{|l|}{ Type of Risk } \\
\hline Biological & Bacteria $^{1}$ & $\begin{array}{l}\text { E. coli, Vibrio cholerae, Salmonella spp., } \\
\text { Shigella spp. }\end{array}$ \\
\hline & Helminths ${ }^{1}$ & Ascaris, Ancylostoma, Tenia spp. \\
\hline & Protozoans ${ }^{1}$ & Intestinal Giardia, Crysptospridium, \\
\hline & Virus $^{1}$ & $\begin{array}{l}\text { Entamoeba spp. Hepatitis A and E, Adenovirus, } \\
\text { Rotavirus, Norovirus }\end{array}$ \\
\hline & Schistosoma $^{2}$ & Blood-flukes \\
\hline Chemical & $\begin{array}{l}\text { Substance of sanitary interest } \\
\text { Heavy Metals }{ }^{2} \text { Hydrocarbons }{ }^{2} \\
\text { Pesticides }{ }^{1}\end{array}$ & $\begin{array}{l}\text { Arsenic, Cadmium, Mercury Dioxins, Furans, } \\
\text { PCBs } \\
\text { Aldrin, DDT }\end{array}$ \\
\hline
\end{tabular}

Note. ${ }^{1}$ Contact and/or consumption, ${ }^{2}$ Consumption.

During the $19^{\text {th }}$ century, wastewater may did not include all pathogens and chemicals listed in Table 1. However, transporting wastewater and disposing it to the open peri-urban areas resulted in catastrophic epidemics of water-borne diseases like cholera and typhoid fever (Felizatto, 2001). Accordingly, the importance of sanitation promoted and organizations such as the World Health Organization (WHO) or the Food and Agriculture Organization (FAO) investigated and published documents to prevent such problems (Seguí, 2004). These organizations still in duty and nowadays they are trying to understand and help countries to deal with Covid-19 disease.

Coronavirus (officially SARS-CoV-2), which cause a respiratory disease called Covid-19, was first detected during an epidemic in the city of Wuhan, China on 12 December 2019, and then spread all over the World. Coronavirus, a family member of Coronaviridae identified during 1960s'. Including SARS-CoV-2, Middle East respiratory syndrome virus (MERS-CoV - 2012), and severe acute respiratory syndrome virus (SARS-CoV, 2003 - China), highly pathogenic strains of Coronaviridae family emerged within last two decades. The size of the coronaviruses is between 60 to $220 \mathrm{~nm}$ and they are enveloped single strained RNA viruses with crown-like spikes on their surfaces (Naddeo \& Liu, 2020). Especially for experts working on water and wastewater, it is very important to have information about the ways of spreading the virus, the problems it causes, and the measures that can be taken to protect workers and public health. For this reason, WHO issued an information note on 19 March 2020, covering viruses, water, public health, and hygiene (WASH), 
including coronavirus, as a contribution to existing infection prevention and control (IPC) documents. It is stated in the information note that COVID-19 has two main ways of transmission which are inhalation and contact. Respiratory transmission is usually caused by the inhalation of viruses on the droplets that are spread around the environment when an infected person coughs or sneezes. Additionally, scattering of the viruses on the surrounding surfaces and getting contact with another person is defined as another way of transmission (WHO, 2020). Although coronavirus has been detected in wastewater and sludge samples (Kocamemi et al., 2020), there is no satisfactory evidence that the virus has been transmitted through water sources or wastewater. Additionally, studies on how long the surrogate coronavirus survives in water and wastewater have pointed out different existence lifetime form month to days (Casanova et al., 2009; La Rosa et al., 2020). However, considering that the risk of infection will increase during epidemic diseases, it is beneficial to take more protective measures for those who are at risk of coming into contact with raw wastewater or wastewater (Medema et al., 2020). Coronavirus in an emerging issue today but, a list of water-borne diseases transmitted directly or indirectly via water listed below in Table 2 also needs to be considered especially in case of reusing wastewater.

WHO published an initial guideline document, "Reuse of effluents: methods of wastewater treatment and health safeguards" in 1973. The latest version of the document published in 2006 and it gives an opinion to decision-makers on the wastewater application. The main purpose of the document is the standardization of the wastewater management within the specific objective of the country (WHO, 2006; Mara et al., 2007; Mara \& Kramer, 2008). Additional to the WHO document, FAO published wastewater quality guidelines to use wastewater in agriculture in 1987 and focused on the degree of restriction of water use of salinity, infiltration, and toxicity parameters of specific ions. After that, the document updated in 1999 and guided about treatment requirements and treated water reuse in agriculture (Ayers \& Wescott, 1985; Pescod, 1992). Not only WHO and FAO focused on the issue but also Environmental Protection Agency (EPA) supports the idea of wastewater reuse might have toxic effects on health and environment when it is used for irrigation and published guidelines document in 1992 and updated the Guidelines for Wastewater Reuse in 2012 with United States Agency for International Development (USAID) (EPA, 2004; EPA, 2012). 
Table 2

Wastewater Related Water-Borne Diseases (Romero, 1996; Von Sperling, 1996; Jiménez \& Rose, 2009; Evans \& Mara, 2011)

\begin{tabular}{cc}
\hline Disease & Cause \\
\hline Typhoid fever & Salmonella typhi \\
Paratyphoid fever $^{2}$ & Salmonella paratyphi \\
Gastroenteritis $^{1}$ & Salmonella typhimurium \\
Cholera $^{2}$ & Vibrio cholerae \\
Bacillary dysentery $^{2}$ & Shigella dysenteriae \\
Amebiasis $^{2}$ & Entamoeba histolytica \\
Giardiasis $^{1}$ & Giardia duodenalis \\
Cryptosporidiosis ${ }^{1}$ & Cryptosporidium \\
Cyclosporiasis $^{2}$ & Cyclospora cayetanensis \\
Infectious hepatitis & Hepatitis A \\
Gastroenteritis $^{2}$ & Enterovirus, parvovirus, rotavirus \\
Infantile paralysis & Poliovirus \\
Leptospirosis $^{1}$ & Leptospira icterohaemorrhagiae \\
Ear infections & Pseudomonas aeruginosa \\
Scabies & Sarcoptes scabiei \\
Trachoma & Chlamydia trachomatis \\
Schistosomiasis ${ }^{2}$ & Schistosoma \\
Malaria & Plasmodium \\
Yellow fever & Flavivirus \\
Dengue & Flavivirus \\
\hline
\end{tabular}

Note. ${ }^{1}$ Human and/or animal excrement, ${ }^{2}$ Human excrement.

In Turkey, wastewater reuse in agriculture is partially regulated. The first regulation accepted on December 1989, is a standardization of irrigation water and called "irrigation water - TS 7739". This standard applies to irrigation water used in the culture of vegetable production, such as water of rivers, lakes, brooks, artesians, spring and other water sources. It does not apply water used for the purpose of drinking and commercial use. The second regulation is published by Ministry of Environment and Forestry of Turkey in 2010, called technical procedure communiqué of wastewater treatment plants given under annex 7 (TSE, 1989; Mevzuat, 2010). However, both of the regulations do not cover pathogenic risks may occur due to de facto reuse of wastewater in the downstream of the effluent. Nowadays, the importance of the subject is rising since it is approved Sars-Cov-2 virus exist in wastewater and increased the need of measure should be taken by governments. 
The main objective of this study is to reveal the results of the "Assessment of Reuse Alternatives of Wastewater" project run by the Republic of Turkey Ministry of Agriculture and Forestry, General Directorate of Water Management. Moreover, sharing the situation of wastewater reuse in agriculture in Turkey and determining the actions need to be taken.

\section{Method}

In the project of 2017/294533 run by Republic of Turkey Ministry of Agriculture and Forestry General Directorate of Water Management "Assessment of Reuse Alternatives of Wastewater", municipal wastewater treatment plants (WWTPs) with the equal or higher capacity of $2000 \mathrm{~m}^{3} / \mathrm{d}$ are focused between years 2017 to 2019 . At first 598 WWTPs identified and in addition to these facilities 3 smaller than 2000 $\mathrm{m}^{3} / \mathrm{d}$ capacity treatment plants included in the inventory and a total of 601 WWTPs were evaluated. Moreover, the data of 328 irrigation facilities operated or transferred by State Hydraulic Works (DSI) with more or equal to 1000 ha evaluated within the project.

Municipalities, DSİ and farmers are the main stakeholders of the project. Many of the WWTPs are visited on-site and gathered detailed information about the process and the current situation of the facilities. Furthermore, data request forms sent to municipalities to share; quantity of water they treat within the last 3 years, water loss rates, water reuse alternatives if it is already available and treatment plant location information with General Directorate of Water Management. Moreover, to have a better understanding of water quality, samples from the effluents collected and analyzed by an accredited commercial lab.

One of the major reuse alternatives was using wastewater in agricultural irrigation. Therefore, the literature reviewed and during on-site visits product pattern of the available agricultural sites investigated and met with local people to understand their needs. Geographical information systems used to evaluate the size of the available agricultural area and to check the potential route of water transportation.

\section{Results}

The performed study showed that 384 of the total 601 facilities are in operation in terms of inventory of the wastewater treatment plants. The number of WWTPs in the project is 89,78 are planned, 35 are under construction, 12 are not operating and 3 are under revision shown in Figure 1. Additionally, the number of WWTPs with varying projected flowrates under 7 categories given in Table 3 . It is figured that 258 
treatment plants applying advanced treatment with a total flowrate of $9.6 \mathrm{hm}^{3} / \mathrm{d}$ which is $49 \%$ of the total treated wastewater covered within this project in a day in Turkey. Moreover, 217 WWTPs having biological treatment and treat $5.2 \mathrm{hm}^{3} / \mathrm{d}$ and it is 27 $\%$ of the total. There are also 17 stabilization ponds and 11 WWTPs with different treatment techniques summarized in Figure 2.

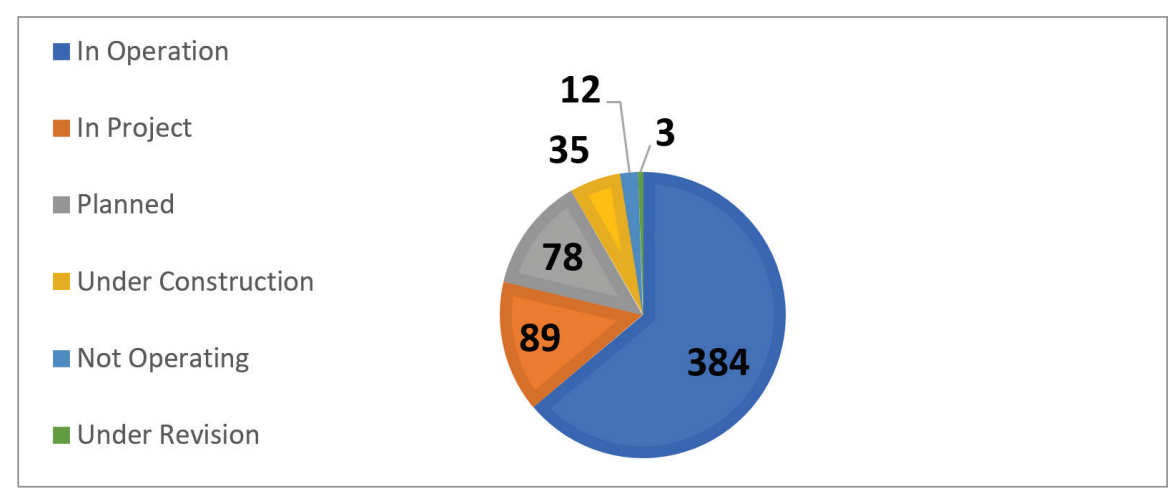

Figure 1. Condition of WWTPs in Turkey with an equal or higher capacity of 2000 $\mathrm{m}^{3} / \mathrm{d}$.

It was evaluated that the total flowrate of wastewater treated by 601 WWTPs is $7113 \mathrm{hm}^{3} /$ year. The reuse option is available for $5615 \mathrm{hm}^{3} /$ year wastewater. In other words, the amount of wastewater that is not possible to reuse is $1498 \mathrm{hm}^{3} /$ year. Although the reuse option is available, in some cases depending on priorities of the stakeholders $47 \%$ of the total wastewater, $3375 \mathrm{hm}^{3} /$ year is recommended to reuse. Furthermore, $60 \%$ of the amount of wastewater recommended to reuse, $2026 \mathrm{hm}^{3} /$ year, is available for agricultural irrigation. In addition, $774,679 \mathrm{~m}^{3} /$ year wastewater pointed to reuse in landscape irrigation.

Table 3

Number of WWTPs with Different Flowrates

\begin{tabular}{ccc} 
No & Projected flowrate $\left(\mathrm{m}^{3} / \mathrm{d}\right)$ & Amount \\
\cline { 2 - 3 } 1 & $<2.000$ & 3 \\
2 & $=2.000$ & 15 \\
3 & $>2,000-5,000 \leq$ & 193 \\
4 & $>5,000-10,000 \leq$ & 131 \\
5 & $>10,000-50,000 \leq$ & 180 \\
6 & $>50,000-100,000 \leq$ & 40 \\
7 & $>100,000$ & 39 \\
\cline { 2 - 2 } & TOTAL & 601 \\
\hline
\end{tabular}


Agricultural reuse of wastewater has a high potential in Turkey. But, it should be applied carefully. Analyzes in the effluent of the wastewater treatment plant have shown that wastewater will have to be subjected to additional treatment before it can be reused even if it is currently treated. It is found that salinity of wastewater is high and incorrect reuse of high salinity wastewater cause salting in the soil. Moreover, microbiologically effluent waters may be a problem in terms of fecal coliform and Escherichia coli. De facto reuse of 221 treatment plants' effluents with a total inflow rate of $6.7 \mathrm{hm}^{3} /$ day are already in use in agriculture. Unfortunately, the result of this study showed that both treatment plants and regulations need to be improved.

The total irrigated area of Turkey is around 6.5 million ha out of the irrigable area. In the activity report (2018) published by DSI, there are 320 irrigation facilities (2.27 million ha) with an area of 1000 ha and more delegated to irrigation unions in charge of operation-maintenance and management responsibilities. 1.8 million ha, $28 \%$ of 6.5 million ha, irrigation facilities operated by the unions indirectly irrigated by wastewater. Provided that in winter and autumn season wastewater is stored in order to be reused, $13 \%$ which is around 245,000 ha (as a comparison, 1.56 times bigger than Harran Irrigation) of the irrigated areas of the facilities operated by the unions can be potentially irrigated with the wastewater shown in Figure 2.

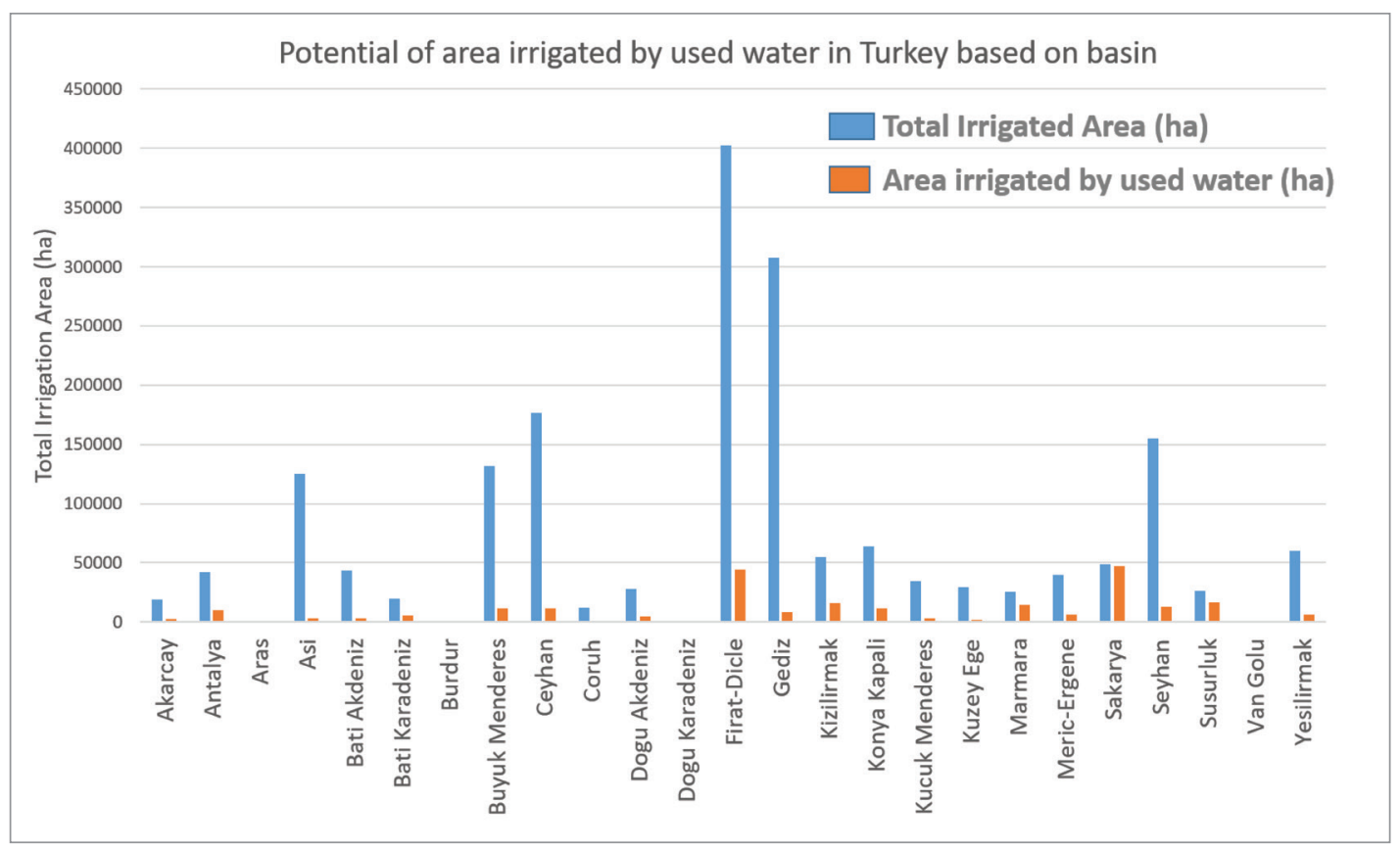

Figure 2. Irrigation area in de facto use of wastewater in Turkey. 
Firat-Dicle and Gediz river basins almost cover $40 \%$ of 1.8 million ha area. There is a wide variety of product patterns in the irrigation areas. For instance, wheat, barley, sunflower, sugar beet, melon, vegetable, fruit, vineyard, citrus, cotton, olive, sesame, corn, etc. many products are irrigated with wastewater. Moreover, it is known that treated wastewater from 92 out of 221 treatment plants is in use to irrigate raw consumable vegetables. Additionally, 50 WWTPs` effluent with the total flowrate of $1.4 \mathrm{hm}^{3} /$ day flow through dams and the majority of them are irrigation dams.

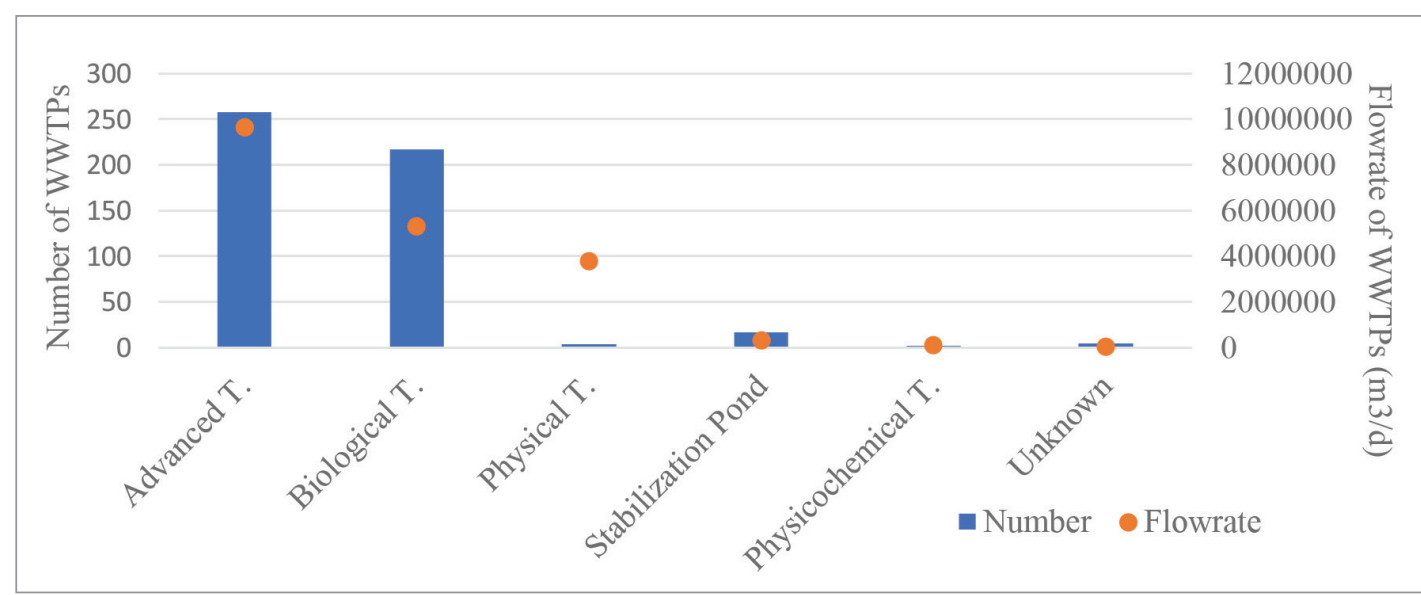

Figure 3. Flowrate and number of WWTPs according to their treatment process.

Only 53 WWTPs with the total flowrate of $1.3 \mathrm{hm}^{3} /$ day in Turkey include disinfection unit between 601 of them. Treatment plants of 221 which are already in use to irrigate, only 42 of them have disinfection unit.

\section{Discussion and Conclusion}

The purpose of this study is to define the current situation and evaluation of actions need to be taken in Turkey in terms of reuse of wastewater in agriculture.

The recent outbreak of coronavirus disease in 2019 has become a public health emergency worldwide. The virus, SARS-CoV-2 is spread by human to human transmission via droplets or direct contact. Although there is no evidence of its transmission from wastewater, the virus has been discovered in wastewater. Recent studies showed that SARS-CoV-2 is very sensitive to oxidants such as chlorine. Therefore, disinfection units of treatment plants need to be operated to avoid virus existence in the environment. Moreover, the disinfection process is vital if treated water is going to be used in irrigation. More than one-third of the effluents of 
wastewater treatment plants in Turkey reaches to agricultural irrigation facilities. The majority of these WWTPs do not have a disinfection unit. Agricultural areas irrigated with treated wastewater have a rich crop pattern. Almost half of these agricultural areas used to grow raw-consumable products. Therefore, disinfection units need to be operated properly and the facilities without disinfection unit should be revised. The disinfection process is important to kill not only the SARS-CoV-2 virus but also especially to destroy pathogens of water-borne diseases.

It is clear that this virus includes uncertainties about infection through wastewater reuse in agricultural irrigation. More detailed research studies should be carried out on this subject. However, this shows that it is an undeniable fact that the process from the wastewater treatment plant to the agricultural irrigation and consumers should be improved and implemented, with a holistic approach to the reuse of treated wastewater, especially in the case of an outbreak. There are one standard and one regulation in terms of reuse of wastewater in irrigation in Turkey. The first regulation called "irrigation water standard" includes several chemicals but does not cover microbiological parameters. The second regulation, "technical procedure communiqué of wastewater treatment plants given under annex 7", published by the abrogated Ministry of Environment and Forestry of Turkey in 2010, and it sets both chemical and biological limits. However, the second regulation only covers direct effluent reuse of treated wastewater. In other words, it does not include de facto reuse of treated wastewater in the downstream. It is inevitable to reuse treated wastewater indirectly in agriculture which may end up with public health tragedy. Therefore, to prevent public health it is needed to update regulations to include indirect reuse of wastewater.

Disinfection process is a vital application in water treatment but, it is also very complicated. Even the aim is protecting public health by disinfection it may end up with formation of disinfection by-products (DBPs), toxic substances in water. Although literature is rich with studies focusing on DBPs formation from natural organic matter (NOM) and in fresh waters, there is still limited information about DBPs formation and speciation from effluent organic matter (EfOM) in treated wastewater effluents. The EfOM of treated wastewater includes more nitrogen-containing compounds than NOM (e.g N/C mass ratios of EfOM and NOM are $\sim 0.20$ and 0.01-0.06, respectively). Additionally, the concentrations of bromide and iodide are higher in wastewater effluents compared to surface waters. Thus, formation of iodinated and brominated DBPs which are more toxic than their chlorinated analogues is favored. Therefore, water quality data and reuse application need to be considered to decide on the suitable disinfection process. 
Treated wastewater is an important alternative to a water source, especially when it comes to the top of climate change adaptation strategies. While these waters will have strategic importance in the water supply in the future, it is obvious that they contain some health risks. However, taking the necessary steps to eliminate these risks has become an indispensable necessity in today's conditions.

\section{Acknowledgement}

This study with the project number of 2017/294533 was supported by the Republic of Turkey Ministry of Agriculture and Forestry General Directorate of Water Management, General Directorate of State Hydraulic Works and MWH Company. 


\section{Numan Habip, Yusuf Başaran, Arife Özüdoğru, Osman Özdemir, Onur Altun, Yakup Karaaslan, Bilal Dikmen / \\ Turkish Journal of Water Science \& Management 4 (2) (2020) / 178 - 192}

\section{References}

Angelakis, A., \& Snyder, S. (2015). Wastewater treatment and reuse: Past, present, and future. Water, 7, 4887- 4895. DOI: 10.3390/w7094887

Ayers, R., \& Wescott, D. (1985). Water quality for agriculture. FAO, Rome, Italy, p. 174.

Casanova, L., Rutala, W. A., Weber, D. J., \& Sobsey, M. D. (2009). Survival of surrogate Coronaviruses in water. Water Research, 43(7), 1893-1898. https://doi.org/10.1016/j.watres.2009.02.002

Environmental Protection Agency. (2004). Guidelines for water reuse. Washington, DC, USA.

Environmental Protection Agency. (2012). Guidelines for water reuse. Washington, DC, USA.

Evans, B., \& Mara, D. (2011). Sanitation and water supply in low-income countries. Leedes, UK: Ventus Publishing.

FAO. (2020). Wastewater treatment and use in agriculture. Retreived May,20, 2020 from http://www.fao.org/docrep/T0551E/ T0551E00.htm.

Felizatto, M. (2001, September 16-21). Projeto integrado de tratamento avançado e reúso direto de águas residuárias. In Proceedings of the 21 Congresso Brasileiro de Engenharia Sanitária e Ambiental. João Pessoa, Brasil.

Angeli, E. L. (2012). Networks of communication in emergency medical services (Publication No. 3544643) [Doctoral dissertation, Purdue University]. ProQuest Dissertations Publishing.

Jiménez, B., \& Rose, J. (2009). Urban water security: Managing risks. New York, NY, USA: UNESCO Publishing.

Kocamemi-Alpaslan, B., Kurt, H., Sait, A., Sarac, F., Saatci, A., \& Pakdemirli, B. (2020). SARS-CoV-2 detection in Istanbul wastewater treatment plant sludges. doi: 10.1101/2020.05.12.20099358

La Rosa, G., Banadonna, L., Lucentini, L., Kenmoe, S., \& Suffredini, E. (2020). Coronavirus in Water Environments: Occurrence, Persistence And Concentration Methods - A Scoping Review. Water Research, 179:115899. https://doi.org/10.1016/j.watres.2020.115899

Mara, D., Sleigh, P., Blumenthal, U., \& Carr, R. (2007). Health risks in wastewater irrigation: Comparing estimates from quantitative microbial risk analyses and epidemiological studies. Journal of Water \& Health, 5, 39-50. DOI: 10.2166/wh.2006.055

Mara, D., \& Kramer, A. (2008). The 2006 who guidelines for wastewater and greywater use in agriculture: A practical interpretation. Efficient management of wastewater; its treatment and reuse in water-scarce countries (pp. 1-17). Berlin, Germany: Springer.

Manga, J., Logreira, N., \& Serrait, J. (2001). Reuso de aguas residuales: Un recurso hídrico disponible. Ingeniería y Desarrollo, 9, 12-21. Retrieved May, 20, 2020 from http://rcientificas.uninorte.edu. co/index.php/ingenieria/article/view/2271/1483 
Medema, G., Heijnen, L., Elsinga, G., Italiaander, R., \& Brouwer, A. (2020). Presence of SARSCoronavirus-2 in sewage. medRxiv. doi: https://doi.org/10.1101/2020.03.29.20045880

Naddeo, V., \& Liu, H. (2020). Editorial perspectives: 2019 novel coronavirus (SARS-CoV-2): what is its fate in urban water cycle and how can the water research community respond? Environmental Science Water Research \& Technology. doi: 10.1039/d0ew90015j

Pescod, M. (1992). Wastewater treatment and use in agriculture. Roma: Organización de las Naciones Unidas para la Agricultura y la Alimentación.

Pimentel, D., \& Pimentel, M. (2008). Food, Energy, and Society. Boca Raton, FL, USA: Taylor \& Francis Group.

Romero, J. (1996). Acuiquímica; Escuela colombiana de ingeniería: Bogotá, Colombia.

Seguí, A. (2004). Sistemas de Regeneración y Reutilización de Aguas Residuales. Metodología para el Análisis Técnico- Económico y Casos (Publication no:10803/7053), [Doctoral dissertation, Universitat Politècnica de Catalunya). Thesis Doctorals en Xarxa.

T.C. Cumhurbaşkanlığı Mevzuat Bilgi Sistemi. (2010). Atıksu Arıtma Tesisi Teknik Usuller Tebliği. Retrieved May, 20, 2020 from : https://www.mevzuat.gov.tr/mevzuat?MevzuatNo=13873\&Mevz uatTur $=9 \&$ MevzuatTertip $=5$

T.C. Tarım ve Orman Bakanlığı Devlet Su İşleri Genel Müdürlüğü. (2018). 2018 Yllı Faaliyet Raporu. Retrieved July, 17, 2020 from http://www.dsi.gov.tr/docs/stratejik-plan/dsi-2018-faaliyet-raporu. pdf?sfvrsn=2

TSE. (1989). Wastewater Sulama Suyu. Retrieved May, 20, 2020 from https://intweb.tse.org.tr/ Standard/Standard/Standard.aspx?081118051115108051104119110104055047105102120088111 043113104073098072050111078079080052089102119

Von Sperling, M. (1996). Princípios do Tratamento Biológico de Águas Residuárias: Principios Básicos so Tratamento de Esgoto; UFMG universitarios: Minas Gerais, Brasil.( p. 243).

World Health Organization . (2006). Guidelines for the Safe Use of Wastewater. Excreta and Greywater in Agriculture. Volume 2. Wastewater Use in Agriculture; Geneve, Switzerland: WHO Press.

World Health Organization. (2020). Water, sanitation, hygiene, and waste management for the COVID-19 virus. s.1.: World Health Organization. 
Numan Habip, Yusuf Başaran, Arife Özüdoğru, Osman Özdemir, Onur Altun,
Yakup Karaaslan, Bilal Dikmen /

Turkish Journal of Water Science \& Management 4 (2) (2020) / 178 - 192

\section{Extended Turkish Abstract \\ (Genişletilmiş Türkçe Özet)}

\section{Kovid-19 Pandemisi Çerçevesinde Türkiye'de Kullanılmış Suların Tarımda Yeniden Kullanılmasının Değerlendirmesi}

Dünya üzerinde suların \%70’i tarımsal sulama amacı ile tüketilmektedir. Bundan dolayı alternatif su kaynaklarının tarımsal sulamada kullanılması her zaman gündeme gelmiş ve antik çağlar da dahil bitkiler kullanılmış sularla sulanmıştır. Kullanılmış suların tekrar kullanılmasının çeşitli avantajları vardır. Tarımsal verimin artması, kullanılmış suyun arıtılması ve dağıtımı için gerekli enerjinin azaltılması başlıca avantajları arasındadır. Ek olarak, atıksular çevreye daha az miktarda deşarj edilir. Ancak, kullanılmış suların tehlikeli kimyasal maddeler ve patojenik mikroorganizmalar içermesi sebebiyle geri kullanımında dikkatli olunması gerekmektedir.

19.yy'da kullanılmış suların kentlerin çevresindeki alanlarda yeniden kullanılması kolera ve tifo epidemisine sebep olmuştur. Sonrasında, sanitasyonun önemi artmış ve Dünya Sağlık Örgütü (WHO), Gıda ve Tarım Organizasyonu (FAO) ve Çevre Koruma Ajansı (EPA) vb. kurumlar konu üzerine çalışmalar yapmış ve kılavuzlar yayımlamışlardır. Yayımlanan kılavuzlarda; atıksuların tarımsal amaçlı tekrar kullanılmasında, kullanılmış sulara uygulanması gereken arıtma metotları ile suyun ulaştırılması gereken kalitesi için kimyasal ve biyolojik parametreleri detaylı olarak ortaya konmuştur.

Yakın zamanda ortaya çıkan Kovid-19 hastalığı sebebi ile dünya çapında acil duruma geçilmiş ve Dünya Sağlık Örgütü tarafından pandemi ilan edilmiştir. Yapılan araştırmalar bu hastalığa yol açan SARS-CoV-2 virüsünün damlacıklar vasıtasıyla veya temas yolu ile bulaştığını göstermiştir. Atıksular yoluyla bulaşmasına ilişkin herhangi bir kanıt olmamasına karşın atıksulardaki varlığı yapılan çalışmalarda gösterilmiştir. Ayrıca, virüsün klor benzeri oksidanlara karşı dayanıksız olduğu ortaya koyulmuştur. Dolayısıyla, virüsün çevredeki varlığının elimine edilmesi için atıksu arıtma tesislerinin dezenfeksiyon ünitelerinin çalıştırılması önem kazanmıştır.

T.C. Tarım ve Orman Bakanlığı, Su Yönetimi Genel Müdürlüğü tarafından yürütülmüşs olan "Kullanılmış Suların Yeniden Kullanım Alternatiflerinin Değerlendirilmesi” projesi kapsamında Türkiye'deki $2000 \mathrm{~m}^{3} /$ gün ve daha yüksek kapasiteli 598 atıksu arıtma tesisi ile 3 adet daha düşük kapasiteli olmak üzere toplam 601 atıksu arıtma tesisi, toplam atıksu arıtma kapasitesi 19,5 $\mathrm{hm}^{3} /$ gün, değerlendirmeye alınmıştır. Bu tesislerden 384 tanesinin işletmede olduğu tespit edilmiştir. Ayrıca, değerlendirmeye alınan tesislerin 258 tanesinin, $9,6 \mathrm{hm}^{3} /$ gün debi ile ileri arıtma tesisi olduğu belirlenmiştir. Biyolojik arıtma tesislerinin sayısının ise 217 olduğu ve toplam 5,2 $\mathrm{hm}^{3} /$ gün debiye sahip olduğu görülmüştür. Yürütülen projede arıtılan toplam atıksuyun $\% 47$ 'si yani $9,2 \mathrm{hm}^{3} /$ gün arıtılmış atıksuyun geri kullanımı önerilmiştir. Yeniden kullanılması önerilen suların ise \% $\% 60$ '1, 5,6 $\mathrm{hm}^{3} /$ gün, tarımsal sulama amaçlı kullanımının uygun olacağı ifade edilmiştir.

Türkiye'nin toplam sulanabilir alanı yaklaşık 6,5 milyon ha'dır. DSİ tarafından yayımlanan raporda (2018), 1000 ha ve daha fazla işletme-bakım ve yönetim sorumluluklarından sorumlu sulama birimlerine devredilmiş 320 sulama tesisi (2,27 milyon ha) bulunmaktadır. 1,8 milyon hektar, 6,5 milyon hektarın \% 28'i olup, kullanılan su ile dolaylı olarak sulanmaktadır. Kış ve sonbahar mevsiminde kullanılan suyun yeniden kullanılmak üzere depolanması şartıyla, birlikler tarafindan 
işletilen tesislerin sulanan alanlarının \% 13'ü [karşıllaştırma olarak 245.000 ha (Harran Sulamadan 1,56 kat daha büyük)] kullanılmış su ile sulanabilecek potansiyeldedir. Güncel olarak 221 atıksu arıtma tesisinin çıkış sularının fiili olarak tarımsal amaçlı kullanıldığı belirlenmiştir. 92 tesisin arıtılmış atıksularının çiğ tüketilen sebzelerin yetiştirildiği alanlarda kullanıldığı tespit edilmiştir. Ayrıca 50 atıksu arıtma tesisinin çıkış sularının sulama amaçlı kullanılan barajlara mansaplandığı belirlenmiştir. Çıkış sularının tarımsal alanlarda kullanıldığı belirtilen 221 tesisin yalnızca 42 tanesinde dezenfeksiyon ünitesi bulunmaktadır.

Bu çalışmanın amacı arıtılmış atıksuların tarımsal amaçlı kullanılması açısından Türkiye'deki güncel durumu ve atılacak adımları belirlemektir. Özellikle arıtılmış atık suları doğrudan veya dolaylı olarak sulamada kullanılan tesislerin deşarj işlemi öncesi dezenfeksiyon uygulaması hayati önem taşımaktadır. Türkiye' deki atıksu arıtma tesislerinin üçte birinden fazlasınınçıkış suyu sulama tesislerine ulaşmaktadır ve bu tesislerin çoğunluğunda dezenfeksiyon ünitesi bulunmamaktadır. Dezenfeksiyon ünitesi bulunan tesislerin de bir kısmı doğru şekilde işletilemez iken bir kısmı dezenfeksiyon işlemi uygulamamaktadır. Türkiye'deki arıtılmış atıksular ile sulanan arazilerin ürün deseni çok çeşitlidir ve yarısından fazlasında çiğ tüketilen ürünler üretilmektedir. Bu sebeple, dezenfeksiyon ünitesi bulunan tesisler uygun şekilde dezenfeksiyon işlemi uygulamalıdır ve dezenfeksiyon ünitesi bulunmayan tesisler revize edilmelidir. Ek olarak, kullanılmış suların sulama amaçlı tekrar kullanılması konusunda halk sağlığını korumaya yönelik kapsamlı bir mevzuat bulunmamaktadır. Kullanılmış suların sulama amaçlı tekrar kullanılması konusunda 1 adet mevzuat ve 1 adet standart olmasına karşın kullanılmış suların mansaplandığı yerlerden dolaylı olarak tekrar kullanılmasını kapsamamaktadır. Dolayısı ile halk sağlığının korunması amacı ile dolaylı olarak kullanılmış suların yeniden kullanılmasını kapsayan mevzuat oluşturulmalıdır. Arıtılmış atık su, özellikle iklim değişikliğine uyum stratejileri konusunda hayati bir su kaynağı olarak önemli bir alternatiftir. Bu sular gelecekte su temininde stratejik bir öneme sahip olsa da, bazı sağlık riskleri içerdikleri açıktır. Ancak, bu riskleri ortadan kaldırmak için gerekli adımları atmak günümüz koşullarında vazgeçilmez bir ihtiyaç haline gelmiştir. 